\author{
Marian Machinek \\ University of Warmia and Mazury in Olsztyn \\ ORCID: 0000-0002-1857-1018
}

\title{
Freedom of Conscience as a Subject of Contemporary Controversies ${ }^{1}$
}

\begin{abstract}
One of the important reasons why the issue of freedom of conscience is one of the most controversial problems of modern times is the ongoing dispute over its definition. In the context of the contemporary emphasis on the moral autonomy of the person, the recent definitions of conscience as the "voice of God" sound at least ambiguous. It is therefore important to point out the various dimensions of conscience. The first and basic one is the individual dimension: conscience is defined as moral selfconsciousness in its deepest, personal dimension. It can therefore, following E. Fromm, be described as the "guardian of moral integrity." However, in addition to this, conscience also points out to "what is common" (J. Ratzinger), to the fundamental values that make social life possible. It is therefore also a carrier of moral truth. Finally, conscience touches upon the relationship with God and this is where its important religious dimension is expressed. It is only when each of these three dimensions of conscience is taken into account that the question of its freedom can be adequately considered. It concerns, above all, the relationship of an individual conscience to an external authority, both in social and ecclesiastical context.
\end{abstract}

Keywords: freedom of conscience, moral integrity, religious obedience, moral law, conscientious objection

${ }^{1}$ The article is a reworked version of the article originally published in Polish: Marian Machinek, "Problematyka wolności sumienia w świetle współczesnych wyzwań," Collectanea Theologica 86 (2016) no. 1, 85-106. Translated from Polish by Maciej Górnicki. 
The atrocities of the II World War have "outraged the conscience 1 of mankind"2 so much that it seemed that an era of respect for the freedom of every person's conscience will arrive. These hopes, after the breakthrough of 1989, spread to the societies which, as a result of Yalta Agreement, had been pushed into life behind the Iron Curtain. It was precisely this deep desire to be able to live according to one's own conscience that was at the root of the opposition that people described as "prisoners of conscience" expressed against the totalitarian state. However, the situation regarding freedom of conscience in a united Europe, but also beyond it, is different from the one that the oppositionists of the second half of the $20^{\text {th }}$ century dreamed of. On the one hand, it would be difficult to speak of any general threat to freedom of conscience. In everyday language, this concept has its meaning as a kind of "flood bank" protecting individual freedom against claims of external authorities. It is hard to fail to see, however, that in the discussion in the fields of philosophical anthropology and theology there is not only a lack of a generally accepted definition of conscience, but there is a tendency to avoid this concept as being blurred and ultimately unnecessary. In a world in which the question of the moral responsibility of artificial intelligence ${ }^{3}$ is being asked in all seriousness, the concept of conscience seems to be long gone. Attempts to value conscience appear almost exclusively in the context of Christian ethics, which gives the impression that it belongs to a mainly religious, and thus to a very narrow discourse. In the social context, invoking conscience can often be seen as a personal whim or even an expression of weakness and oversensitivity. Any analysis of freedom of conscience must therefore begin by attempting to point out definitional problems relating to the understanding of conscience itself. Differences in this understanding lead directly to a different diagnosis of claims and conflicts on a social level.

\footnotetext{
${ }^{2}$ United Nations, Universal Declaration of Human Rights (1948), https://www.jus. uio.no/lm/en/pdf/un.universal.declaration.of.human.rights.1948.portrait.letter.pdf [access: 22 IX 2020].

${ }^{3}$ The question, whether robots can be provided with, or develop, a conscience, is considered in: M. van Creveld, Conscience. A biography, Reaktion Books: London 2015, pp. 215-220.
} 


\section{The Definitional Problems of Conscience}

A preliminary analysis of the problem of conscience shows that, although the very concept of conscience only emerged in ancient Greece as a result of long deliberations, the very experience of conscience, or more accurately, of conflicts of conscience, is one of the most primordial experiences of a self-aware human being. The first step must be to point out three basic dimensions of conscience: individual, communal and religious.

\subsection{The individual dimension: "The guardian of our integrity"}

Describing conscience in this way, Erich Fromm pointed out its crucial importance in shaping personal moral integrity. It is precisely the subjective dimension of conscience that undoubtedly comes to the fore in this ongoing debate. The concept of conscience is often closely linked, above all, to the subjective moral sense of the moral self-awareness of the person. It is not, however, some kind of power separate from human reason, but rather a specific personal dimension of that reason, which provides man with an orientation not only in the world of things, but also in the moral space, in the world of values. Individual conscience has as its content the entirety of the moral concepts and values that a particular person possesses, that is to say, the knowledge of good and evil, of moral norms, but also the spontaneous valuations that have emerged as a result of previous moral experiences. ${ }^{4}$ Such an approach undoubtedly captures an important dimension of conscience, which determines human dignity. Conscience, to use a popular comparison, is the arena in which the drama of human freedom is played out. As the famous Munich theologian Romano Guardini stated, "conscience is that element in our consciousness that is attributed to good and together with it constitutes the whole of the moral reference - to the extent that we can say: to act morally is to act

\footnotetext{
${ }^{4}$ N. Dent, "Conscience", in: E. Craig (ed.), Routledge Encyclopedia of Philosophy, Routledge: London-New York 1998, pp. 579-581.
} 
according to one's own conscience, assuming that this conscience is what it should be like in its essence." 5

The subjective dimension of conscience is primarily concerned with the plane of important life choices for the individual. There is no doubt that it is precisely conscience that will have a decisive influence on moral choices concerning, for example, life's journey or political commitment. These will, of course, be individual choices, often difficult even to justify objectively, and will meet with incomprehension and sometimes even resistance from other people; choices arising from the individual moral sensitivity of a particular person and the unique situation in which he or she finds him/herself. An example of faithfulness to such a subjective voice of conscience will be the attitude of the Austrian Pallottine Franz Reinisch, who was beheaded on 21 August 1942 for his refusal to take the oath to Hitler. When, as a conscript, he was urged by his friends and superiors to be submissive and asked not to recklessly put his life in jeopardy, Reinisch pointed to this very personal decision of conscience: "I know that many priests think different. But every time I examine my conscience, I cannot come to a different result. And I cannot act and, with the grace of God, do not want to act against my conscience. As a Christian and an Austrian, I am unable to take an oath of allegiance to someone like Hitler [...]. There must be people who protest against the abuse of power, and I feel called upon to do so." ${ }^{.6}$ Characteristic of this justification is, on the one hand, the individual, personal reference to a specific moral decision, and, on the other hand, the absence of a claim to generalize such an attitude, although such generalization would be possible or even necessary in this case. ${ }^{7}$ It goes without saying that individual

5 R. Guardini, Ethik. Vorlesungen an der Universität München, vol. 1, Grünewald/Schöningh: Mainz-Paderborn 1993, p. 97.

${ }^{6}$ Quote after: E. Schocknehoff, Jaka pewność daje nam sumienie? Orientacja etyczna, transl. A. Marcol, Wydawnictwo WTUO: Opole, pp. 40-41.

${ }^{7}$ Reinisch was not an isolated case of conscientious objection in the Third Reich. In 2007, Pope Benedict XVI beatified Franz Jägerstätter, who also refused to serve in the Nazi army, for which he was executed in 1943. Biographers say that the great confirmation for Jägerstätter's awaiting execution in prison was the news from the prison chaplain about the steadfast attitude of Franz Reinisch, who was executed 
decisions based on such an individual dimension of conscience must not concern clearly irrational issues. However, as was the case with opposition to the Nazi regime and other totalitarian systems, they can be a kind of reproach for the silent attitude of society. The moral obligation to oppose unjust structures and not to participate in sustaining them can undoubtedly be considered a universal moral imperative, but the form in which this opposition is expressed will already depend on personal moral sensitivity. The testimonies of martyrs of conscience show that they understand the duty to express their opposition as a personal call, felt by some, while others experience it in a different way.

The individual dimension of obedience to conscience understood in this way does not usually arouse controversy. However, can this uniqueness and subjectivity of assessment apply to all moral principles and norms? In other words, does the conscience exhaust itself in the subjective aspect? This statement seems to be supported by the specificity of moral cognition. The good that must be done and the evil that must be avoided never appears in abstract form, but always in a specific situation. Only the person concerned is able to fully recognise the complexity of the moral challenges involved. ${ }^{8}$ Thus, one can undoubtedly speak of a "creative" role of conscience, if one understands it as a kind of "management" of the space of personal responsibility, which general norms are only able to outline, but not fill with concrete content. ${ }^{9}$ However, the point of dispute here is the very existence and application of these general norms. Will the "creativity" of conscience consist in selectively invalidating or respecting them, depending on the situation?

There is no doubt - and this has always been the position of Catholic moral theology - that conscience is the proximate norm

a year earlier. Cf. J. Schwabeneder, „Kurzbiografie von Franz Jägerstätter“, in: A. Riedl, J. Schwabeneder (ed.), Franz Jägerstätter, Christlicher Glaube und politisches Gewissen, Thaur: Wien, München 1997, p. 20.

${ }^{8}$ Cf. K. Demmer, Fundamentale Theologie des Ethischen, Herder: Freiburg, Wien 1999, p. 185.

${ }^{9}$ E. Schockenhoff, Jaka pewność daje sumienie?, p. 184. 
of personal morality, ${ }^{10}$ which must not be opposed and which must be followed. But this is not the end of Catholic reflection on conscience. For if one were to consider conscience not only as a direct, but as the ultimate and infallible norm of morality, it would be difficult to explain the real difference of opinion between the consciences of individual people. It would also be difficult to distinguish between the attitude of someone who deserves to be called a "martyr of conscience" and the actions of, for example, a terrorist who, referring to his conscience, makes an attack. What unites these two categories of people may, after all, be a similar certainty of conscience about the necessity of doing so. In an attempt to explain this difference of opinion, therefore, we should either blame God for the behaviour of the terrorist offensive to human dignity (since conscience is the voice of God in man, which will be discussed further on), or we should treat his actions as a certain acceptable variant of human action, adding only that they should only be carried out in accordance with a deep conviction of conscience (since conscience is the individual norm of personal morality). Already at first sight, both options are absurd. Here we are touching upon another dimension of conscience which, from a Catholic point of view, is as essential as the individual dimension discussed above.

\subsection{The communal dimension: \\ "The window for common truth"}

There is no doubt that an individual's conscience can be wrong. Admittedly, Catholic theological and moral reflection does not share the extremely negative pessimistic assessments of conscience in the style of, for example, Arthur Schopenhauer (conscience is $1 / 5$ of fear of people, 1/5 of suspicion, 1/5 of prejudice, 1/5 of vanity and 1/5 of habituation ${ }^{11}$ ), Sigmund Freud (conscience is the internalisation

\footnotetext{
${ }^{10}$ See: John Paul II, Veritatis splendor, no. 60, http://www.vatican.va/content/johnpaul-ii/en/encyclicals/documents/hf_jp-ii_enc_06081993_veritatis-splendor.html [access: 22 IX 2020].

${ }^{11}$ Cf. B. Sill, Gewissen. Gedanken, die zum Denken geben, Bonifatius: Paderborn 2006, pp. 247-248.
} 
of external authorities in the form of a superego ${ }^{12}$ ) or Friedrich Nietzsche (the source of conscience is faith in authorities; it is therefore the voice of certain people in $\operatorname{man}^{13}$ ). There is no doubt, however, that conscience is not an ability that in all its wealth is immediately fully educated and remains constant. Thomas Aquinas claimed that although conscience, understood as a habitus, which was described in the late Middle Ages as a synderesis ${ }^{14}$, and which carries with it both the very ability to distinguish between good and evil and the duty to do good and avoid evil, as well as the most general and fundamental moral principles, is innate and unchangeable, yet in the act of conscience, concerning the evaluation of a specific act (which Thomas describes as conscientia), an important role is also played by acquired knowledge of facts (scientia) and by life's moral experience (sapientia). ${ }^{15}$ Due to the latter, acquired and changing factors, in a concrete assessment conscience can be wrong.

Nineteenth and twentieth-century psychological and sociological reflection has deepened and critically analysed these multiple dependencies of conscience on external influences. In this context, the need for education and self-education of conscience should be stressed, but at the same time the question should be raised as to whether there is any fixed point of reference for conscience in the process of education in the form of objective moral principles. A negative answer to this question would lead to the conclusion that the education of conscience consists of a simple internalisation of accepted social norms in order to reduce the spaces of conflict

12 S. Freud, "Das Ich und das Es", in: idem, Das Ich und das Es. Metapsychologische Schriften, Fischer: Frankfurt/Main, pp. 287-292.

${ }^{13}$ F. Nietzsche, "Menschliches, Allzu menschliches. Ein Buch für freie Geister", in: idem, Werke in drei Bänden, vol. 1, Carl Hanser: München ${ }^{8} 1977$, p. 902.

${ }^{14}$ See: Observations on the medieval science of synderesis: R. Sorabji, Moral conscience trough the ages. Fifth century BCE to the present, The University of Chicago press: Chicago 2014, pp. 60-65.

15 Thomas Aquinas, De Veritate, q 17 a. 1. See: some detailed considerations about the medieval notion of synderesis and conscientia by R.J. Smith, "The nature and function of conscience according to St. Thomas Aquinas", in: R.J. Smith (ed.), Conscience and Catholicism. The nature and function of conscience in contemporary catholic moral theology, University Press of America: Lanham, New York, Oxford 1984, pp. 1-44. 
between the individual and society. Catholic theological-moral reflection has always stressed the conviction that there are objective moral principles that result from the order of reality and the nature of the human person. These principles simply reflect the fundamental requirements necessary to preserve the dignity of the person, to protect his or her fundamental goods and values and the well-being of society. If the conscience were limited to the individual, we would reduce man, as a moral subject, to a selfcontained monad. ${ }^{16}$

An act of conscience is, however, a judgment, that is, a cognitive act. What is known in this act is not only the state of mind of the person, but also the moral dimension of reality. As Tadeusz Styczeń expressed it, the judgment of conscience "obliges us [...] not so much and not only because it is our own and issued by us, but also because it is a message about what it obliges us to do. The judgment does not, therefore, create a moral obligation by itself, it is not a generator in the sense of some genetic and at the same time methodological a priori moral obligation. It merely communicates it to the subject." 17 Alongside the personal call for a specific action or omission, therefore, man feels a duty which, in his view, concerns not only himself, but every other person. In other words, I feel not only that $I$ must not do something, or that $I$ should do something, but that something must not be done by anyone, or that everyone should do it. Alongside the personal and unique moral challenges that the individual dimension of conscience brings with it, something that we could define as an objective dimension of morality is revealed in it, that is to say, as the Church's Magisterium often emphasises, moral truth, truth about good.

${ }^{16}$ In his speech to the Members of the Bundestag during his pilgrimage to Germany, Pope Benedict XVI drew attention to this danger: "[T]he positivist reason which recognizes nothing beyond mere functionality resembles a concrete bunker with no windows, in which we ourselves provide lighting and atmospheric conditions, being no longer willing to obtain either from God's wide world. [...] The windows must be flung open again, we must see the wide world, the sky and the earth once more and learn to make proper use of all this. See: Benedict XVI, The Listening Heart. Reflections on the Foundations of Law (Visit to the Bundestag, 22 September 2011, http://www.vatican.va/content/benedict-xvi/en/speeches/2011/september/ documents/hf_ben-xvi_spe_20110922_reichstag-berlin.html [access: 23 IX 2020]. 17 T. Styczeń, Wprowadzenie do etyki, TN KUL: Lublin 1995, p. 134. 
The constitutive bond of conscience with this truth prevents becoming locked in the subjectivity that would inevitably lead to isolation and, consequently, to the blindness of the individual conscience. To illustrate this unique relationship between the subjective and objective dimensions in the individual conscience, Cardinal Joseph Ratzinger uses a very simple comparison, which he often repeats. If one were to agree with individualistic concepts, he claims, then the whole truth about the subject would be reduced to his subjective truth-thinking and truth-telling. This would mean that there is no door or window in man which would lead from the subject into the broader world of being (Germ. das Ganze) and human solidarity (das Gemeinsame). ${ }^{18}$ These terms are intended to indicate the whole truth about the human person. As Ratzinger points out, only the openness of an individual conscience enables a person to see what is most important, "[...] and so makes possible through the common recognition of truth, the community of needs and responsibilities." 19 It is through conscience that a meaningful dialogue between people is and remains possible, even beyond the boundaries of religion. Thanks to its openness to the fundamental values of human existence, conscience can be defined as a binding point (Knotenpunkt) and a place for integrating the dialogue between Christians and non-Christians. We are touching here on the third dimension of conscience, which is its religious dimension.

18 J. Ratzinger, "Conscience and Truth." Presented at the 10th Workshop for Bishops February 1991 Dallas, Texas, https://www.ewtn.com/catholicism/library/ conscience-and-truth-2468 [access: 25 IX 2020].

${ }^{19}$ Ibid. See: also a statement of pope Benedict XVI during his apostolic journey to Croatia: Benedict XVI, Meeting with representatives of civil society, political, cultural and business world, diplomatic corps and religious leaders, Zagreb 4 June 2011, http://w2.vatican.va/content/benedict-xvi/en/speeches/2011/june/documents /hf_ben-xvi_spe_20110604_cd-croazia.html [access: 19 IX 2020]: “If, in keeping with the prevailing modern idea, conscience is reduced to the subjective field to which religion and morality have been banished, then the crisis of the West has no remedy and Europe is destined to collapse in on itself. If, on the other hand, conscience is rediscovered as the place in which to listen to truth and good, the place of responsibility before God and before fellow human beings - in other words, the bulwark against all forms of tyranny - then there is hope for the future." 


\subsection{The religious dimension: "The aboriginal Vicar of Christ"}

This somewhat archaic expression of the famous English convert, John Henry Newman, ${ }^{20}$ whose strong influence on twentieth-century Catholic theological reflection is indisputable, should not lead to overhasty simplifications. This expression refers to the traditional definition of conscience as "the voice of God." In the sanctuary of his conscience, as stated in the Council Constitution Gaudium et spes (no. 16), man not only encounters himself, but is also alone with God. This thought was already expressed by Saint Augustine, according to whom man in his conscience faces not only God (coram Deo), but it is there that God is closer to man than he is to himself; there God is interior intimo meo. ${ }^{21}$ St Augustine seems to be based here on the classic statement of the Apostle of the Nations, who - as the historical-critical analysis clearly shows ${ }^{22}$ - introduced the concept of syneidesis, known in popular ancient philosophy, into Christian theological thought, obviously modifying its meaning. For him, this co-knowing is no longer, as for the ancient pre-Christian and non-Christian philosophers, merely the self-awareness of the acting subject, that is to say, moral self-reflection, but God himself co-knows the moral quality of actions, as well as the motivation of the acting subject. To take a metaphor from the Book of Sirach, one can therefore describe conscience as the "eye of God" in the human heart (Sir 17:8).

\footnotetext{
${ }^{20}$ J.H. Newman, A letter addressed to the Duke of Norfolk on occasion of Mr. Gladstone's recent expostulation, 248-249, https://www.ecatholic2000.com/ newman/duke-07.shtml\#_Toc431032889 [access: 19 IX 2020]: "Conscience is the aboriginal Vicar of Christ, a prophet in its informations, a monarch in its peremptoriness, a priest in its blessings and anathemas, and, even though the eternal priesthood throughout the Church could cease to be, in it the sacerdotal principle would remain and would have a sway."

${ }^{21}$ Saint Augustine, The Confessions, III, 6, 11, transl. H. Chadwick, Oxford: Oxford University Press, 1992.

22 The word syneidesis occurs 30 times in the NT, including 14 times in the Corpus Paulinum and 16 times in other writings. It is evident that this word does not occur at all in the Gospels. It only appears in the pericope of the adulteress (Jn 8:9) and only in some manuscripts, documented only since $8^{\text {th }}$ century AD. This state of matters makes it possible to suppose that it was precisely Paul who introduced the term syneidesis into Christian theology.
} 
Such an understanding of conscience has a long extra-Christian tradition, although not related to the concept of syneidesis itself, but clearly to this specific experience which contemporary ethical reflection clearly identifies as an experience of conscience. From Aschilles' Erynia to Sophoclean "gods' [...] unwritten and unchanging laws," 23 all the way up to the Socratic daimonion, ${ }^{24}$ God's messengers can push man towards non-conformist attitudes, forcing him, if unavoidable, to stand in opposition to those in power, and even give his life for loyalty to his own beliefs. As a witness to an already mature reflection on ethics, devoid of any mythological elements, one can recall Seneca, who in one of his letters to Lucillius speaks of a god who "is near you, he is with you, he is within you." And he adds: "[A] holy spirit indwells within us (sacer intra nos spiritus sedet), one who marks our good and bad deeds, and is our guardian (malorum bonorumque nostrorum observator et custos)." 25 This seemingly almost Christian ${ }^{26}$ text must of course be read in the context of ancient pantheism, where it has a meaning different than Christian.

Regardless of the similarities, the specific Christian importance of speaking of conscience as the "voice of God" should be very strongly emphasised. For this voice is not experienced in the human conscience as the voice of a stranger, coming as it were from outside. Otherwise, one should recognize the accusations of critics, for whom defining conscience as the voice of God would mean a heteronomisation of morality and a denial of moral autonomy. However, the voice of conscience is not the voice of a competitor and rival who forcefully enters into human rational reflection and forces something incompatible with his own moral consideration. As the Australian bishop and bioethicist Anthony Fisher jokingly

\footnotetext{
23 Sophocles, Antigone 450, transl. I. Johnston, Vancouver Island University: Nanaimo, BC, Canada 2005.

${ }^{24}$ Platon, Phaeudrus 242c, transl. B. Jowett, http://www.gutenberg.org/files/1636/ 1636-h/1636-h.htm [access: 23 IX 2020].

${ }^{25}$ Seneca, Moral letters to Lucilius, Letter 41, transl. R.M. Gummere https://en.wiki source.org/wiki/Moral_letters_to_Lucilius/Letter_41 [access: 23 IX 2020].

${ }^{26}$ Seneca the Younger (Lucius Annaeus Seneca also known as Seneca the Younger) died in 65 C.E., so it would be difficult to exclude a certain impact of early Christian reflection on his views.
} 
states, "if we experience such voices we should probably see a doctor or an exorcist!" 27 Nevertheless, it is not just one's own voice, an effect of a kind of dialogue with oneself, because then man would have power over it. But, as Martin Heidegger aptly put it, "[T] he call comes from me and yet from beyond me (aus mir und dennoch über mich)." 28 The religious dimension of conscience makes it possible to explain the apodictic nature of its judgments, which not only describe a moral reality, but also, together with the recognition of good and evil, make the right choice and can violently deny a deliberately wrong choice.

Understanding conscience as God's voice is closely linked, on the one hand, to the Christian image of God and, on the other, to the Christian concept of man. By emphasising God's freedom and omnipotence, Catholic theology is not leaning towards a voluntary approach, for which the independence of God's will would involve the arbitrary establishment and change of moral norms by God, while man's task would be merely blind obedience to these arbitrary decisions, without attempting to explain them rationally. God undoubtedly remains the ultimate norm of morality (norma ultima moralitatis), but morality is linked to the essence and order of the world He created. Something is good not because it has been commanded by God, but it has been commanded by Him precisely because it is good. Catholic anthropology has always stressed that the human reason has capacity for moral cognition, that is to say, to know the order of creation, an ability that original sin has not been able to annihilate, although it has seriously weakened it. Generally speaking, therefore, to recall once again the image used by St Paul, the Torah, or God's social and moral order, was inscribed in human hearts (Rom 2:15). God, therefore, does not need, in order to use a certain colloquialism, to "control" man "by hand," as it were, "from the back seat," because He has given him reason, capable of seeing the moral message that is revealed in man himself, and thus

\footnotetext{
27 A. Fischer, Catholic bioethics for a New Millenium, Cambridge University Press: Cambridge 2012, p. 38.

${ }^{28}$ M. Heidegger, Being and time, transl. J. Macquarrie, E. Robinson, Blackwell: Oxford, Cambridge, 1962, p. 320. Another translation: "[T]he calling comes from me and at the same time it has authority over me."
} 
in the nature of the human person, as well as in all created reality. ${ }^{29}$ Even without a conscious faith in God, therefore, man is able to recognise good and evil, at least in fundamental matters, by following his moral reason (conscience) as long as it has not been corrupted. A righteous conscience (conscientia recta) will be able to respond to the moral challenge of a concrete situation adequately and in agreement with the truth about good. In this way, in the religious dimension of conscience, the individual and community dimensions converge, complementing and verifying each other. One way of verifying the personal and individual dimension of conscience will be to consider whether what I believe God requires of me is not contrary to objective moral standards.

As John Paul II stated in his Encyclical Dominum et vivificantem, "[t]he conscience therefore is not an independent and exclusive capacity to decide what is good and what is evil. Rather there is profoundly imprinted upon it a principle of obedience vis-a-vis the objective norm which establishes and conditions the correspondence of its decisions with the commands and prohibitions which are at the basis of human behaviour." 30

\section{The Problem of Conscience in the Public Sphere}

It is time to relate these reflections concerning the definition and understanding of conscience to contemporary challenges. At the same time, the controversies mentioned above over the various dimensions of conscience mark the main points of the dispute that is currently taking place, on the one hand, within Christian denominations and between secular and Christian ethics, but, on the other hand, also in the public and media space, where the subject of conscience is of considerable interest. To the fore comes the relationship of an individual conscience to an external authority, both secular, which is the state and the laws made under it, and

\footnotetext{
${ }^{29}$ The conviction that reality, and in it human nature, is transparent to God's moral message is at the heart of the concept of natural law.

${ }^{30}$ John Paul II, Encyclical Dominum et vivificantem on the Holy Spirit in the Life of the Church and the World, No 43, http://www.vatican.va/content/john-paul-ii/en/ encyclicals/documents/hf_jp-ii_enc_18051986_dominum-et-vivificantem.html [access: 24 IX 2020].
} 
religious, which for a Christian is the Church and the moral convictions stemming from faith, expressed in her moral teaching and legislation.

\subsection{The freedom of conscience in a pluralist society}

As mentioned above, paradoxically, it would be difficult to define modern pluralist society as a kingdom of freedom of conscience. The problem is probably already rooted in the very concept of pluralism. On a de facto level, pluralism of worldviews is indisputable. There are different points of view and related moral assessments. To put it simply, one could say that there are different consciences that should in principle be respected in the rule of law. There is also no doubt that forcing anyone to act contrary to their conscience, as well as preventing individuals from acting in accordance with their conscience, is not compatible with the order proper to the rule of law. This is also the teaching of the Catholic Church, particularly with regard to the sphere of religious beliefs, as expressed in the Council's declaration Dignitatis humanae. ${ }^{31}$ Does this, however, really mean the neutrality of the state's worldview? In other words, in the face of pluralism of values, can the state take a completely indifferent position by treating all worldview options as equivalent? It has to be said that there is no such possibility, because then it would also have to consider as equivalent to others

\footnotetext{
${ }^{31}$ Second Vatican Council, Declaration on religious Freedom Dignitatis humanae (7 December 1965), http://www.vatican.va/archive/hist_councils/ii_vatican council/documents/vat-ii_decl_19651207_dignitatis-humanae_en.html [access: 24 IX 2020]: "This Vatican Council declares that the human person has a right to religious freedom. This freedom means that all men are to be immune from coercion on the part of individuals or of social groups and of any human power, in such wise that no one is to be forced to act in a manner contrary to his own beliefs, whether privately or publicly, whether alone or in association with others, within due limits. [...] This right of the human person to religious freedom is to be recognized in the constitutional law whereby society is governed and thus it is to become a civil right. It is in accordance with their dignity as persons-that is, beings endowed with reason and free will and therefore privileged to bear personal responsibility-that all men should be at once impelled by nature and also bound by a moral obligation to seek the truth, especially religious truth. They are also bound to adhere to the truth, once it is known, and to order their whole lives in accord with the demands of truth."
} 
those options which, for example, support slavery, are based on the assumption that there are classes of people with different dignity, allow the extermination of innocent people or question the very existence of the rule of law. Without a certain fundamental consensus on fundamental values and their institutional protection and implementation (e.g., in the education system), peaceful social coexistence, and therefore the very existence of the rule of law, would not be possible at all. Therefore, as we read in the Polish Constitution, for example, the state is not and cannot be neutral, but should be impartial as to the worldview. ${ }^{32}$ On the one hand, this means that solutions based on different ethical assumptions can be proposed in public debate. On the other hand, however, it also means that there is a boundary of the absolutely fundamental values that cannot be legitimately questioned. The freedom of individual conscience will therefore have its limitations, not only linked to the freedom of other individuals, but also to certain pillars of the moral order, without which there is an inexorable threat of collapse of the rule of law.

And it is here, as it seems, that worrying shifts are taking place, affecting the issue of freedom of conscience. One of these shifts is the blurring of the moral foundations of the rule of law, which as such should not be disputed. It is claimed that society does not have to rely at all on moral foundations connected with the nature of the human person, but such foundations can be created by free discourse aimed at achieving a consensus. ${ }^{33}$ Such a view means not only negating the objective dimension of morality, but also the objective dimension of conscience, which is what Cardinal Ratzinger has described as sensitivity to values common to all. What remains is the subjective conviction of individual consciences, which no longer

\footnotetext{
32 The Constitution of the Republic of Poland, Art. 25.2: "Public authorities in the Republic of Poland shall be impartial in matters of personal conviction, whether religious or philosophical, or in relation to outlooks on life, and shall ensure their freedom of expression within public life."

${ }^{33}$ This is the well-known thesis of Jürgen Habermas, the nestor of European philosophy, which seems to be a real but unwritten basis for the functioning of international institutions, including the European Union. See:

Ch. Larmore, "The Foundations of Modern Democracy: Reflections on Jürgen Habermas", European Journal of Philosophy 3 (1995) no. 1, pp. 55-68.
} 
have any objective points of reference except the temporary consensus of the given society. This consensus is not just the result of moral reflection, but is achieved under pressure from intense media propaganda. The role of state authority and lawmaking is reduced to protecting the freedom of individual consciences, and tolerance of different points of view becomes a leading value. However, the binding point of reference is not completely abandoned, but it is no longer the nature of the human person. The concept of normative human nature, which defines fundamental values, is cancelled out as unjustified essentialism and biologism and replaced by a strongly modified concept of human rights. Originally, these meant precisely the fundamental rights that stem from human nature and are therefore common to all human beings. The Historical Universal Declaration of Human Rights of 1948 refers to the "inherent dignity" of every human being. Nowadays, the reference point is the "development" of human rights, containing the social and cultural demands and claims of various minorities and pressure groups. They are described as inviolable because they allegedly set the highest possible standards of human rights, which must not be invalidated under any circumstances. This creates a new kind of secular dogma, the rank of which exceeds that of an individual conscience. Anyone who does not want to comply with these newly set standards by invoking their conscience is accused of discrimination and violation of fundamental human rights.

The consequences of such approach can be best shown on the concrete area of the freedom of conscience of the health care workers. In theory, the freedom, and even the duty, to act in accordance with one's conscience is guaranteed to the health care employees in medical codes, including the Polish Code of Medical Ethics (Articles 4 and 41). However, this guarantee, as it turns out, may not be sufficient if the doctor actually decides to refuse to provide services on the grounds of conscience. The provision in the Act on the Professions of Doctor and Dentist that was in force until recently contained inconsistent and to some extent contradictory provisions, which, while granting a doctor the right to use the conscientious objection clause, at the same time drastically limit this right, obliging him/her to redirect the patient to another doctor who will perform the requested treatment (Article 39). In fact, therefore, 
a doctor who refuses an abortion, for example, would have to personally take care of a list of those who potentially perform abortion and formally refer the person requesting it to such a doctor. Even if the conscientious objection clause were used, the doctor would have to cooperate in carrying out the act which he or she is opposed to. What is crucial here is that this is not about some subjective conviction of the doctor resulting strictly from his or her private views (in other words, the individual dimension of conscience discussed above), but about a fundamental ethical precept of the medical profession (and thus its appeal to what is common), which prescribes that the life and health of the patient be treated as the highest and leading value. By opposing the performance of an abortion, which violates everyone's right to life, the doctor wishes to show not only that he or she is not able to perform the procedure, but that no doctor should do so. A similar obligation put on the opposing doctor to indicate another entity to perform a rejected medical service is contained in the legislation of many European countries. This form of law was revised in Poland after being appealed to the Constitutional Court. In 2015, it was declared unconstitutional in this regard.

Following the discussion on the shape of medical care in Poland, especially in the context of ethically controversial medical services, we can see a worrying tendency to treat the conscientious objection of medical opponents in terms of moral hypersensitivity, a certain personality weakness which, although it should be tolerated to a certain extent, should in principle be seen as a significant shortcoming. A doctor's professionalism (and therefore his/her potential for promotion and career) would depend on the absence of conscientious objection and his/her willingness to do all the services that are legally permissible without objection, regardless of the judgment of conscience, which is considered here only to be a private matter. This is confirmed by the position of the Bioethics Committee of the Bureau of the Polish Academy of Sciences of 12 November 2013 on the conscientious objection clause, the signatories of which are concerned about the fact that doctors are allegedly abusing this clause to the detriment of patients' 
autonomy. ${ }^{34}$ The impression is given that the doctor (and another health professional) is expected to be a kind of extension of the state's alleged neutrality of the worldview. He or she is expected to take a position that is somewhat above the various options, without taking account of his/her own conscience. As the then Minister for Health, and later (2014/15) the Polish Prime Minister, once put it, conscience is to be left in the waiting room of the cabinet where the person holds public office. Using pictorial language, one could say that the official is supposed to take it off like a coat. The ideal would therefore be a doctor with no conscience, who strictly follows the procedures without asking further questions. ${ }^{35}$

John Paul II noticed these troubling tendencies many years ago. Addressing on $18^{\text {th }}$ June 2001 Catholic obstetricians and gynaecologists, he pointed out to the problems resulting from these tendencies: „Until quite recently, medical ethics in general and Catholic morality were rarely in disagreement. Without problems of conscience, Catholic doctors could generally offer patients all that medical science afforded. But this has now changed

${ }^{34}$ See: The position of the Bioethics Committee of the Bureau of the Polish Academy of Sciences of 12 November 2013 on the conscientious objection clause. See: http://www.bioetyka.pan.pl/images/stories/Pliki/Stanowisko\%20KB\%20nr\% 204-2013.pdf [access: 31 I 2015]. See also a dissenting opinion on this position by Sr. Professor Barbara Chyrowicz: http://www.bioetyka.pan.pl/images/stories/Pliki/ 4-2013-Chyrowicz.pdf [access: 31 I 2015].

${ }^{35}$ Resolution 1763 of the Parliamentary Assembly of the Council of Europe of 7 October 2010, in which the following is stated, should be regarded as an unexpectedly different voice from this worrying trend: "No person, hospital or institution shall be coerced, held liable or discriminated against in any manner because of a refusal to perform, accommodate, assist or submit to an abortion, the performance of a human miscarriage, or euthanasia or any act which could cause the death of a human foetus or embryo, for any reason." See: Council of Europe. Parliamentary Assembly, The right to conscientious objection in lawful medical care, Resolution 1763 (2010), http://assembly.coe.int/nw/xml/XRef/Xref-XML2 HTML-en.asp?fileid=17909 [access: 24 IX 2020]. See also the attempt to build an institutional compromise on references to conflict of conscience in the area of health care: H.F. Lynch, Conflicts of conscience in health care. An Institutional compromise, the MIT Press: Cambridge, MA, London 2010. 
profoundly." ${ }^{36}$ In the face of these tendencies John Paul II stressed the demand for the right to the freedom of conscience, stating, "The conflict between social pressure and the demands of right conscience can lead to the dilemma either of abandoning the medical profession or of compromising one's convictions. Faced with that tension, we must remember that there is a middle path which opens up before Catholic health workers who are faithful to their conscience. It is the path of conscientious objection, which ought to be respected by all, especially legislators." 37

The situation of freedom of conscience in the health services can be regarded as a paradigm of social change linked to the negation of the objective dimension of morality, the consequence of which is the inevitable flattening of the concept of conscience. As it turns out, these changes, paradoxically, do not lead to the promotion of conscience and an increase in its true freedom, but to its marginalisation.

\subsection{The freedom of conscience in the Church}

When discussing the issue of freedom of conscience in the public space, it is also important to mention that part of it which comprises the intra-church space. At first glance, we are dealing here with a situation analogous to the one discussed above, that is to say, a relationship between an individual's subjective conscience and external authority. The opposition of these two instances seems to be further strengthened by the existence of an ecclesiastical Magisterium within the Catholic Church, which expects the faithful to obey its statements on faith and morality. ${ }^{38}$ Within the framework of Catholic theological and moral reflection, there is no shortage of voices which, by analogy with the relationship between the individual and civil authority, advocate the subjective rightness of

\footnotetext{
${ }^{36}$ John Paul II, Address on the occasion of the international congress of catholic obstetricians and gynecologists, (18 June 2001), http://www.vatican.va/content/joh n-paul-ii/en/speeches/2001/june/documents/hf_jp-ii_spe_20010618_obstetriciansgynaecologists.html [access: 21 IX 2020].

37 Ibid.

38 See: Second Vatican Council, Dogmatic Constitution on the Church Lumen gentium, no. 25 .
} 
an individual conscience in a situation of conflict with the official teaching of the Church. The statements of the Magisterium would bind the individual, like those of other "expert" voices, only on condition that the individual understands and accepts a particular moral instruction. ${ }^{39}$

Such approach, however, does not take into account the significant differences between the secular and ecclesiastical context of an individual's relationship to authority. First of all, it is difficult to define the Church by analogy with society as a worldview-wise pluralist community. On the contrary, it is rather a community based on a common faith and morality in fundamental issues, and therefore worldview-wise homogeneous by definition and nature. Reaching for the Pauline term, there is such a thing as typos didachess (cf. Rom 6:17), the precepts of doctrine, that is to say, a binding form of life by faith which is closely linked to the Good News of the liberating and transforming power of God expressed in the kerygma. ${ }^{40}$ Secondly, joining or actually remaining in the Church is a matter of voluntary decision and can be reevaluated at any time, even when someone has been incorporated into the Church by others through baptism received in childhood. The state and the Church are not equivalent realities, and therefore leaving the Church does not mean depriving one of the possibility of a decent existence. Thirdly and finally - and this is probably where the key to resolving the dispute in the title lies - the Church's Magisterium with the Pope at the head are not instances that stand above conscience and seek to replace it.

Also, in the Church completely blind obedience, i.e., a complete renunciation of the judgment of one's conscience in favour of the Magisterium, would be a denial of one's dignity. It is worth recalling here once again the figure of John Henry Newman, who in his famous letter to the Duke of Norfolk faced the accusation that

${ }^{39}$ S. Ernst, Grundfragen theologischer Ethik, pp. 120-121.

${ }^{40}$ As Cardinal J. Ratzinger emphasizes, "every morality needs a certain 'we' with its pre-rational and supra-rational experience, in which the wisdom of generations is intertwined, and not just a calculation related to the present moment." See: J. Ratzinger, Der Auftrag des Bischofs und des Theologen angesichts der Probleme der Moral in unserer Zeit, Internationale Katholische Zeitschrift Communio 13 (1984), p. 528. 
through their obedience to the Pope, Catholics are moral and mental slaves. Newman does not accept such radical opposition, but considers conscience and the Magisterium to be at the service of the same moral truth, which for every believer creates a duty to be known and respected in his decisions. The Magisterium is the voice that expresses the Church's moral experience, which, in the face of the fallibility and limitations of the individual conscience, can be of decisive help to it. As Newman says, "The championship of the Moral Law and of conscience is his raison d'être [of the papal authority]. The fact of his mission is the answer to the complaints of those who feel the insufficiency of the natural light; and the insufficiency of that light is the justification of his mission." ${ }^{41}$ The fundamental obedience of the Magisterium will not offend an individual's conscience as long as he or she is able to recognise that the Magisterium itself is not the result of an unjustified human usurpation, but is part of the visible structure of the Church desired by Christ.

Obviously, even where fundamental obedience to the Magisterium is acknowledged, there may also be a conflict between the subjective conscience and the teaching of the Magisterium. It must then be borne in mind that there is a hierarchy of truths in the Church, linked to a hierarchy of preaching and with various binding powers. There is a legitimate plurality of views on issues that are still unresolved and secondary, as well as on many issues concerning personal vocation, tasks and life choices. In such conflict situations a lot will depend not so much on doctrinal statements as on the personality of the parties to the dispute. For this is never a conflict of individual conscience with an anonymous Magisterium, but always a conflict of consciences: the conscience of an individual faithful person and the conscience of a person who performs a pastoral function. A lack of patience, transparency and goodwill on both sides can often cause deep wounds.

Despite this, however, it is difficult to describe the permanent contestation of the Church's moral teaching on fundamental issues

${ }^{41}$ J.H. Newman, A letter addressed to the Duke of Norfolk on occasion of Mr. Gladstone's recent expostulation, 253, https://www.ecatholic2000.com/newman/ duke-07.shtml\#_Toc431032889 [access: 19 IX 2020]. 
as a faithful dissent. In the case of such a dissent, there is a duty to seek the truth and there must be enough time to do so. However, when this discord persists and is protracted, then the question of Catholic identity becomes prominent. The negation of fundamental principles of morality, as they are understood and taught by the Magisterium, based on a different judgment of one's own conscience, simply touches the very foundations of being a Catholic. One cannot at the same time claim the right to be a Catholic and deny the fundamental moral principles of the Catholic faith.

\section{Conclusion}

It seems that the fundamental problem in the contemporary debate on freedom of conscience is not only the subjectivisation of morality at individual level, but also social and political changes. These may lead to morality, with all the basic requirements and moral principles common to all, being replaced by a kind of "technology of behaviour," the aim of which will be, on the one hand, to enlarge the area of tolerated behaviour and, on the other hand, to exclude opinions and behaviours which are in conflict with the requirements of political correctness. It is not difficult to predict that a civilisation devoid of values, built on such a foundation, will not be a civilisation of love and life and will not be able to survive. In the face of such dangers, it is Christians who - as Cardinal Joseph Ratzinger stated in one of his essays - should have "the courage to live according to conscience and so keep open the narrow pass between anarchy and tyranny, which is none other than the narrow way of peace." 42

\footnotetext{
42 J. Ratzinger, Turning Point for Europe? The Church in the Modern World: Assessment and Forecast, transl. B. McNeil, San Francisco: Ignatius Press, 2010, p. 61 .
} 